\title{
The social order of markets
}

\author{
Jens Beckert
}

Published online: 27 January 2009

(C) The Author(s) 2009. This article is published with open access at Springerlink.com

\begin{abstract}
In this article I develop a proposal for the theoretical vantage point of the sociology of markets, focusing on the problem of the social order of markets. The initial premise is that markets are highly demanding arenas of social interaction, which can only operate if three inevitable coordination problems are resolved. I define these coordination problems as the value problem, the problem of competition and the cooperation problem. I argue that these problems can only be resolved based on stable reciprocal expectations on the part of market actors, which have their basis in the socio-structural, institutional and cultural embedding of markets. The sociology of markets aims to investigate how market action is structured by these macrostructures and to examine their dynamic processes of change. While the focus of economic sociology has been primarily on the stability of markets and the reproduction of firms, the conceptualization developed here brings change and profit motives more forcefully into the analysis. It also differs from the focus of the new economic sociology on the supply side of markets, by emphasizing the role of demand for the order of markets, especially in the discussion of the problems of valuation and cooperation.
\end{abstract}

Markets are the central institutions of capitalist economies. The development of modern capitalism can be viewed as a process of the expansion of markets as mechanisms for the production and allocation of goods and services. This applies not just to labor markets, which only emerged on a significant scale with industrialization, but also to the organization of the production and distribution of consumer and investment goods, services, and commodities. The increasing separation of the economy from the household and its organization through market exchange allowed for a scope in the development in the division of labor and production of wealth that would otherwise have been unattainable.

J. Beckert $(\bowtie)$

Max-Planck-Institut für Gesellschaftsforschung, Paulstr 3, 50676 Köln, Germany

e-mail: Beckert@mpifg.de 
No one seriously questions the central role of markets in capitalism. This makes it all the more surprising how restricted the attention has been to the study of markets in modern economic theory, but also in the other social sciences that address economic subject matter. For a long time, modern economics focused only in a very limited way on markets. General equilibrium theory, as the heart of neoclassical economic theory, analyzed the formation of efficient distribution equilibria via the market. The interest here was not in studying the empirical functioning of markets and its institutional preconditions (Coase 1988: 7-8; Lie 1992: 508), but rather in the mathematical proof of efficiency postulates, conducted under a variety of simplifying assumptions. These include not just the assumption of the flexibility of prices, but also, in particular, assumptions concerning the characteristics of goods as well as the actors' rationality and information supply. Neoclassical economic theory thus has not so much a theory of the market as a "pure theory of exchange" (White 1990: 3).

In its founding phase, sociology was interested in the institutional preconditions for markets, as reflected especially in the work of Max Weber (Weber 1978) and Émile Durkheim (Durkheim 1947). By the post-war period, however, sociologists interested in economic structures were far more concerned with analyzing the organization of industrial production processes. Only labor markets received more intensive attention. The reason for this may be sought in the strong state influence in the organization of post-war economies, which curtailed the impact of the market mechanism (Djelic 2006: 59), but also in the influence of Talcott Parsons and his suggestion for the division of labor between economics and sociology (Beckert 2002: 135ff). Later, the orientation towards Marxist approaches with their primary interest in exploitation in the sphere of production contributed to a de-emphasis on markets in sociological scholarship as well.

It was only developments in economics and sociology since the 1970s and the 1980s, respectively, that put markets back in the spotlight as a field of empirical study (Krippner 2001; Lie 1997; Swedberg 2003: 115). In this article, I sketch the constitutive concern situated at the core of the sociology of markets and outline the research problems that must be addressed in order to understand the operation of markets. I argue that the core issue of the sociology of markets is to explain the order of markets. How is it possible that economic activities can be coordinated through markets despite the heterogeneous and partly antagonistic motives and interests of the participants? By coordination I mean that actors succeed in aligning their actions in ways that allow for market exchange to take place because they can form expectations about what others will do and because the expected behavior of others is sufficiently compatible with their own material or ideal interests. This notion of coordination corresponds to the concept of "mutual coordination," i.e., "to act together in a smooth concerted way" (Klein 1997: 326). It also matches the use of the term in convention theory, where coordination is understood as "agreement" among actors "about what is to be done" (Storper and Salais 1997: 16). Such coordination is a precondition to what I call the order of markets.

My point of departure is that markets are highly presuppositional arenas of social interaction in which actors are confronted with profound coordination problems. "[A]n actor subject to uncertainty must make an effort to determine how to coordinate successfully with other actors to deal with the situation at hand. This 
makes the central problem one of producing coordination among actors" (Storper and Salais 1997: 14). While redistribution and reciprocity also entails coordination problems, these problems become much more taxing in markets. This is not only because market behavior cannot be aligned through a chain of command or through tradition but also because capitalist economies constantly create new markets and destroy old ones, which leads to a continuous reentering of uncertainty both inside the economy and outside of it. Due to the emergence of new markets, the entering of new market actors in existing markets and changing strategies of market actors, the order of markets is in a dynamic flux, where actors oscillate between the search for stability and the destruction of this stability.

I argue that three coordination problems in the sense of "mutual coordination" can be analytically distinguished: I call them the value problem, the problem of competition, and the cooperation problem. These coordination problems can only be resolved if market actors are able to form stable expectations with regard to the actions of other market actors and future events relevant for their decisions, and if they consider the expected outcomes to be sufficiently in their material interest and normatively acceptable. In this sense markets are understood as "fully social institutions, reflecting a complex alchemy of politics, culture, and ideology" (Krippner 2001: 782). While the notion of the "order of markets" refers to the macrolevel result of the solution of the three identified coordination problems, the expectations formed by actors constitute the building blocks of this order on the actor level.

In line with other sociological approaches to markets, I pursue the argument that market actors' expectations are formed by the structural, institutional and cultural embeddedness of market exchange (Dobbin 2004a; Fligstein 2001a; Granovetter 1985; White 1981). This reveals market exchange to be a form of social interaction that cannot be explained by a "natural propensity to truck, barter and exchange" (Smith 1976: 17), but only by the institutional structures, social networks, and horizons of meaning within which market actors meet. While the conceptualization is informed by the new economic sociology and especially by the work of Neil Fligstein (Fligstein 1996, 2001a, b), it differs from it at the same time on several accounts: Instead of focusing primarily on the stability of markets and the reproduction of firms, it brings change and profit motives more forcefully into the analysis. It also differs from the focus of the new economic sociology on the supply side of markets, by emphasizing the role of demand for the order of markets, especially in the discussion of the problems of valuation and cooperation. Finally, market struggles are not understood as being confined to struggles between producers but as also entailing a conflict between the economy and wider social spheres. I contribute to the sociological conceptualization of markets the distinction between the three coordination problems, each of which has been extensively discussed individually, but which have not been recognized as forming a comprehensive tableau of founding problems for the sociology of markets. If the order of markets depends on the resolution of the three identified coordination problems and if this resolution depends on the formation of stable expectations on the side of market actors, the task of market sociology is to study both the emergence and change of the social macrostructures relevant in the market context and the structuring of market actionand the distribution of exchange opportunities - by these macrostructures. 
In the first part of the article, I provide a brief outline of the analysis of markets in several economic approaches and in economic sociology with reference to the vantage point just sketched. In the second part, I introduce and discuss the three coordination problems based on a theoretical explanation of why these problems comprise the central subject matter for the sociological analysis of markets. In the third part, I counter the impression that a sociological approach to markets centered on the order of markets would lead to a static perspective by developing a model of the dynamic changes of markets, arguing that the dynamics of markets emerges from a constant oscillation between the stabilization and destabilization of expectations. This is followed by a brief conclusion.

\section{The social order of markets}

Markets are arenas of social interaction. They provide a social structure and institutional order for the voluntary exchange of rights in goods and services, which allow actors to evaluate, purchase, and sell these rights (Aspers and Beckert 2008). Markets contain not only the element of exchange but are characterized by competition, which means that the existence of a market presupposes at least three actors: one on one side of the market confronting at least two other actors on the other side whose offers can be compared. "A market may be said to exist wherever there is competition, even if only unilateral, for opportunities of exchange among a plurality of potential parties" (Weber 1985, Vol 1: 635). Actors on both sides of the market interface have partly similar and partly conflicting interests: while they must both be interested in the exchange of a good, they have conflicting interests regarding the price and other specifications of the contract from which a "price struggle" between them emerges that results - if the exchange is to take place - in a compromise between the exchange partners.

How is it that economic production and distribution can be successfully organized through markets? At first sight, this may seem to be a pointless question, since billions of market transactions take place "silently" every day, and the coordination of the production and distribution of commodities via the market thus appears to be quite unproblematic. Only by adopting an outside perspective do we realize how presuppositional and thus improbable the coordination of economic processes via markets actually is. For all market actors the organization of economic activities through markets entails risks that seem to make it unlikely that they would entrust their economic well-being to this mechanism: The producer may not find a buyer for his product at a profitable price, either because potential purchasers do not need it or because a competitor captures his business. Buyers and sellers may not fulfill their contractual responsibilities, defrauding their exchange partners instead. The product may not possess the promised qualities. Buyers do not know whether they might not be able to purchase the product more cheaply or in a better quality elsewhere, or whether the purchase of another product will turn out to be more profitable. Workers do not know whether their labor power will meet a demand in the labor market. These examples show that market exchange is full of contingencies beyond the control of single actors and, thus, of a high degree of uncertainty in regard to outcomes. The contingencies of market exchange make markets precarious arenas of 
social interaction, the "functioning" of which is anything but self-evident. Only when it is possible to integrate the individual behavior of market actors in such a way that they develop enough confidence to accept the risks of market exchange can the market operate as a mechanism for the fulfillment of adaptive functions in society. But how can we explain this integration of action and thus the order of markets?

\section{Economics}

The most influential answer to this question is provided by liberal economic theory and is based on the assumption that actors participate in market exchange out of self-interest. According to this view, "social order" can be stabilized in markets because exchange offers advantages to the individual participants. The liberal train of thought is not limited to explaining individual participation in markets, but entails a theory of social order as well. The coordination of economic activities through markets leads to an efficient allocation of economic resources where exchange takes place until no actor can increase his or her utility further without making at least one actor worse off (Pareto optimality). This explanation of the stability and efficiency of markets, however, depends on far-reaching assumptions regarding the way actors make decisions and the information they have with which to make them. As long as one takes for granted that these assumptions are being met, one can explain the order of markets in terms of the self-interest of participating actors and restrict the study of markets to the creation of equilibria through price adjustment. "[O]rder is grounded in each agent acting rationally to maximize his or her own preferences within the constraints of a competitive economy" (Gould 1991: 92-93; cf. also Hirschman 1986: 123). To invert the argument, this means that the problem of order returns as soon as we depart from the idealized assumptions of neoclassical theory with its "single exit" solutions (Latsis 1972).

Large parts of the development of economic theory since the 1970s have been attempts to understand what would happen to the equilibrium model if one changed its assumptions: if one abandoned the premise of complete information and radicalized the economic model of action in a Hobbesian manner.

The two most important lines of research here are information economics (Akerlof 1970; Stigler 1961) and the new institutional economics (North 1990; Richter and Furubotn 2003; Williamson 1975, 1985, 2000). Information economics abandons the assumption that actors are completely informed about the quality of a commodity. The paradigmatic point of departure for this line of research is George Akerlof's essay "A Market for Lemons" (Akerlof 1970), in which he shows that assuming an asymmetrical distribution of information - the potential buyer of a used car knows less about the characteristics of the automobile for sale than the seller-no market for used cars develops, that is, market failure ensues. The solution proposed by the economics of information involves the introduction of safeguarding institutions by vendors, such as guarantees on used automobiles or investment in the vendor's reputation, which reduce the purchasers' risks (of buying a "lemon") and increase their willingness to purchase. The market is less efficient in this case than it would be if all parties were fully informed, but market failure can be avoided. 
The new institutional economics radicalizes the action assumptions of neoclassical theory by giving up the notion (asserted since the beginnings of modern economics) of an "honest merchant" who acts based on his or her self-interest, while at the same time respecting the property rights of others (Hirschman 1987). This assumption is supplanted by a Hobbesian model of action centered around the notions of "opportunism" and "self-interest seeking with guile" (Williamson 1975: 255). In this model of action, it is assumed that an agent will opportunistically seek his own advantage, and, if this is in his or her interest, do so also by ruthlessly violating the interests of his or her exchange partner in the process. Opportunism and "bounded rationality" (Simon 1955) comprise a situation of uncertainty, which causes market failure. Market institutions, which are explained based on their contribution to efficiency, permit the stabilization of market actors' expectations by guarding against opportunism, thus helping to make markets possible.

The new economic sociology

The new economic sociology, whose development over the past twenty years has made the study of markets an important subject of sociological research once again, also takes up the problem of explaining the order of markets (Aspers 2005; Fligstein 2001a; Podolny 2005; Swedberg 2003; White 2001). In doing so, however, it does not share the individualist basis of economic theories. ${ }^{1}$ From the sociological perspective the departure from the assumptions made by standard neoclassical economics have far more serious consequences for the understanding of markets than economic approaches assume, because they fundamentally challenge explanations of ordering processes that proceed from an individualistic vantage point and contest an understanding of institutions as efficient responses to uncertainty.

Two phenomena account for this: First, social macrostructures are devised in a field structured by already existing institutional regulations, making institutional continuities and changes dependent on past occurrences, and the equipment of actors with power deriving from their positions within the market field (Streeck and Thelen 2005; Djelic and Quack 2007: 163ff). The existing market structures are a social force patterning future developments which must not follow a path toward increased efficiency.

Second, the uncertainty actors confront keeps them from being able to predict which strategies and institutional structures will lead to an optimal outcome. It is impossible for actors to anticipate what would be the optimal institutional design (Beckert 1996, 2002; Jagd 2007: 77ff). The imponderables that result from strategic uncertainty and the essential unpredictability of future events belie an understanding

\footnotetext{
${ }^{1}$ Émile Durkheim's (Durkheim 1984) concept of the non-contractual elements of contract makes it clear that the observance of contracts by market parties presupposed in neoclassical theory could not be explained solely in terms of the interests of the participating actors. Max Weber's (Weber 1978, 1992) explanation of the development of the institutional foundations and individual action dispositions against the backdrop of which modern western capitalism arose is also not based, in terms of contract theory, on the self-interest of the participants, but rather on power-saturated political processes and religious transformations. Institutions are thus not to be understood as efficient responses to information problems.
} 
of market action that proceeds from atomized, utility-maximizing actors. ${ }^{2}$ Actors do not have the calculative bases for optimizing their utility functions in the face of bounded rationality, social interdependence and new action situations (Beckert 2002: $7 \mathrm{ff}$ ). In consequence, uncertainty leads actors to resort to socially anchored scripts or "conventions" that serve as a "collectively recognized reference" (Orléan, quoted in Jagd 2007: 79), providing orientation for intentionally rational actors in situations where optimal responses cannot be foreseen. ${ }^{3}$ These "substitutes" for optimizing in the sense of economic theory reduce uncertainty based on culturally anchored understandings of situations, allowing actors to make sense of the complex circumstances of the decisions they face and to coordinate their interactions. Hence individual decision making must be understood within its social contexts that lead to the "framing of markets" (Fiss and Kennedy 2007). Sociological explanations of the emergence, stability, and change of institutions and their effects on market interaction thus differ fundamentally from the economic approach: Institutions are understood not from a contractarian perspective as the efficient result of an agreement of socially unbound individuals, but rather as situated within a specific political, social and cultural context that constitutes the actors' goals, strategies, and cognitive orientations.

It is, however, not only that uncertainty provides the background to the embeddedness of economic action; uncertainty is also a critical element of the dynamics of markets (Beckert 2002; Deutschmann 1999). It is only in situations where outcomes cannot be fully rationally calculated and are therefore not determined by "single exits," that "new combinations" (Schumpeter) are possible which provide profit opportunities that can be seized by entrepreneurs who "breach previously separated spheres" (Granovetter 2002: 44). Uncertainty opens up opportunities for entrepreneurial activity and is therefore a necessary condition for the dynamic change of capitalist economies. Due to this link with practices of dynamic change, uncertainty ties the question of the order of markets to the dynamic development of this order.

In the past twenty years, the concept of embeddedness has become established in economic sociology as a categorical instrument for describing the ordering processes that lead to a reduction of the uncertainty and the social structuring of decisions in markets (Granovetter 1985). ${ }^{4}$ The differentiation of the concept of embeddednessZukin und DiMaggio (Zukin and DiMaggio 1990) distinguish between social, cultural, political, and cognitive embeddedness - points to different approaches in market sociology. What these approaches share is the assumption of actionstructuring social macrostructures. However, each stresses a different social

\footnotetext{
${ }^{2}$ In game theory, the idea of the "institution as the equilibrium outcome of a game" was introduced to resolve this problem (Schotter 1981: 155). Institutions are understood here not as "rules of the game" as they are in the new institutional economics, but rather as a Nash equilibrium in a repeated non-cooperative game. This solution, however, demands perfect rationality and thus has preconditions that neither the new institutional economics nor economic sociology anticipates. On this, see Richter 2000).

${ }^{3}$ Furthermore, in non-cooperative games like the prisoner's dilemma, cooperative strategies lead to more efficient outcomes, also rejecting rational actor theory as a normative theory of utility maximization.

${ }^{4}$ The use of the term in the new economic sociology, however, has little in common with its meaning in the work of Karl Polanyi, to whom the concept is generally attributed (Beckert 2007; Krippner 2001).
} 
macrostructure shaping market outcomes (Dobbin 2004a; Fligstein and Dauter 2007; Fourcade 2007). The network approach associated particularly with the works of Mark Granovetter (Granovetter 1985, 2002) and Harrison White (White 1981, 2001), emphasizes the social embeddedness of market actors. By contrast, the institutional approach, which is associated with the work, for instance, of Neil Fligstein (Fligstein 2001a), Frank Dobbin (Dobbin 1994) and Bruce Carruthers (Carruthers 1994; Carruthers and Halliday 1998), primarily stresses the institutional embeddedness of market exchange. ${ }^{5}$ Finally, the third approach in the sociology of markets, which shows significant overlaps with the institutional approach, is centered on notions of cultural and cognitive embeddedness, emphasizing the meaning structures relevant in the behavior of market actors (DiMaggio 1994; MacKenzie and Millo 2003; Meyer and Rowen 1977; Zelizer 1979, 1994, 2007). ${ }^{6}$

\section{Value, competition and cooperation as central coordination problems}

The explanation of economic outcomes in terms of social contexts is the common denominator in the differing approaches to market sociology (see Dobbin 2004b). While innumerable empirical studies based on the three above-mentioned approaches demonstrate the role played by social macrostructures in the explanation of economic outcomes, when it comes to addressing theoretically the systematic problems to which the embeddedness of economic action is actually a response, they remain largely silent. ${ }^{7}$ How is it possible to integrate interaction in a social arena

\footnotetext{
${ }^{5}$ While the concept of cultural embeddedness has not produced an independent school of thought within the sociology of markets, it has asserted itself strongly in various combinations with the network approach and the institutional approach (Bourdieu 1999; Bourdieu 2005; DiMaggio 1994; Zelizer 1979). Political embeddedness, along with discussions of the state regulation of markets, is associated with the institutional approach. By emphasizing the importance of formal institutions and state regulation in constituting and stabilizing markets, some authors associated with the institutional approach exhibit an affinity to comparative political economy, and its attribution of different national strategies of firms to the specific institutional structures of national economies (Hall and Soskice 2001: 4ff). Comparative political economy, however, focuses on the explanation of entrepreneurial strategies rather than the analysis of market relations. As a result, comparative political economy is far more interested in the production problems of firms. The observed coordination problems focus on the question of how and under what conditions firms gain access to the resources they need to manufacture products (Hall and Soskice 2001: 4). Market sociology, in contrast, stresses the coordination problems that arise in the exchange of goods or services, drawing more attention to the exchange processes themselves and to the demand side.

${ }^{6}$ The more recently developed performativity approach (Callon 1998; MacKenzie, Muniesa, and Siu 2007 ) is further away from institutionalism. It stresses the role of economic theories in explaining the structuration of markets (Garvia 2007) and actor strategies in markets (MacKenzie and Millo 2003). This enables it to demonstrate that the way economic actors think about the functioning of markets actually shapes markets by aligning organizational structures, strategies, and reciprocal expectations of market participants.

${ }^{7}$ The new economic sociology has focused so strongly on demonstrating the embeddedness of market action by means of empirical investigation that an important question has been virtually disregarded: Which theroretical issues can be addressed by focusing on the embeddedness of market behavior? Frequently, programmatic statements aimed at defining a future research agenda for economic sociology either stress approaches (Dobbin 2004b) or identify appealing empirical research topics (Carruthers 2005: 346ff; Zelizer 2007).
} 
populated by actors with highly diverse backgrounds and conflicting interests? I contend that the coordination problems faced by market actors in the complex and uncertain situations in which they make decisions are at the heart of a sociological approach to markets. The notion of the "order of markets" expresses in abstract terms the explanandum of the sociology of markets.

I argue that one can distinguish between three fundamental coordination problems which represent at the same time the central sources of uncertainty for market actors. Their resolution is a precondition for the order of markets and fixes distributional outcomes from market exchange which lead to social stratification. I call these issues the value problem, the problem of competition, and the cooperation problem. These three themes provide a comprehensive tableau of the relevant coordination issues in markets. The sociology of markets must be able to demonstrate its contribution to the understanding of these coordination problems relative to economic approaches that often address the very same questions, and which in their most advanced expressions have undergone a "sociological turn" (Greif 2006: XV).

I discuss the three topics in turn, addressing for each of them the questions of how social macrostructures contribute to the resolution of the problems at hand and how the emergence and change of these macrostructures can be explained. This framing of the sociology of markets rejects the distinction between network approaches, institutional approaches, and cognitive advances since networks, institutions, and cognition are seen as complementary in the resolution of the cited problems. ${ }^{8}$

The value problem

The value problem refers to the constitution of actor preferences and thereby stresses the demand side of markets, which is ignored by many approaches in the sociology of markets (Fligstein 2001a; White 1981). One crucial source of uncertainty confronting market actors derives from the difficulties of assessing the value of commodities. Given the multiplicity of goods and their complex quality properties, demanders have trouble "forming clear subjective values for goods in the market" (Koçak 2003: 8). Only when potential purchasers are in a position to distinguish between the values of goods, and sellers can reliably demonstrate the value of their goods, will uncertainty be reduced and a disposition to buy arise (Koçak 2003: 5-6).

This is a central initial problem of market sociology, referring to the constitution of demand, which finds no place in neoclassical economic theory. The latter assumes preferences to be given and stable, and thereby exogenizes their emergence and change. ${ }^{9}$ This led to Talcott Parsons' critique (Parsons 1949) that economic theory was caught up in a "utilitarian dilemma." What he meant was that economic theory either explained action goals on the basis of behaviorist determinism or had to leave

\footnotetext{
${ }^{8}$ While there is a general unease with regard to the separation of these three approaches in economic sociology (Fourcade 2007: 1026), few articles address this problem explicitly. One excellent exception to this is (Djelic 2004), who shows the connections between networks and processes of institutionalization.

${ }^{9}$ The notion of revealed preferences used by economists (Samuelson 1938) does not provide a theory of preference formation but looks at preferences post hoc.
} 
them unexplained, viewing them as random tastes: De gustibus non est disputandum (Stigler and Becker 1977). This did not mean that neoclassical theory was wrong, but that it contained a central limitation, since it could not explain the arisal of preferences or the assignment of value to goods. Parsons' solution consisted in the introduction of ultimate values on the basis of which actors determine their action goals, which points to the social - and not individualist - constitution of preferences. How, though, are we to understand the processes of classification and commensuration with which actors assign value to goods?

(1) The value problem is concerned, on the one hand, with the assignment of different values to heterogeneous products within the same market. The classification may be based on standards that make it possible to offer objective quality descriptions of products in relation to other products of the same class. Thus, the determination of the load-bearing capacity of steel springs from different alloys on the basis of technical testing would be an example of a technically defined classification for the purposes of quality distinction, which can form the basis of value differentiations. Different steel springs of a specified quality offered by different producers in the market can then be compared based on price, and preferences can be formed. The basis for the classification is a technical standard. Yet, even such classifications aimed solely at establishing the functional value of a product in relation to others can be unambiguous only in the case of very simple products. Once products turn out to be more complex, the valuation criteria themselves become contested and must be established in political and social processes. The question of what criteria to apply in assessing the value of used cars also depends on conventions established in a technical field. The same holds true, for instance, in decisions concerning the selection of personnel. Although employers aim to hire the best or most suitable employees, the question of what criteria should be used to establish an employee's qualification is subject to dispute among experts, changes over time and differs between countries (Segalla et al. 2001; EymardDuvernay and Marchal 1997). The analysis by MacKenzie and Millo (MacKenzie and Millo 2003) of the creation of the Chicago Board Options Exchange shows how the valuation of stock options became possible with advances in finance theory and the development of technologies making the theory easily applicable for traders. Value assessment is based on a financial theory that coordinates action of market participants by providing a cognitive basis from which to judge the relative value of heterogeneous products within the market.

The social processes behind the constitution of value become fully visible if we turn to a market where objective standards of quality assessment play no role at all. The market for contemporary art is such a market where actors have no recourse to standards reflected in the product itself. In this market, assessments of value are established in interactive processes of recognition within the field of art itself. It is the recognition an artist finds among reputable and influential members of the art world, such as art critics, museum curators, galleries and collectors, that establishes the quality of his or her work (Becker 1982; Beckert and Rössel 2004; Velthuis 2003). Much the same is true of the wine market (Diaz-Bone 2005; Rössel 2007). Although it is ultimately the individual buyer who decides what price he or she is willing to pay for a product, the assessment of value is not entirely of his or her own making, but rather relies on socially constructed judgements that reduce uncertainty 
and thereby stabilize expectations in a market field. "Confusion over the product's identity" (Zuckerman 1999: 1398) itself affects the value of goods. If the classification of firms in terms which industrial sector they belong to is unclear, it becomes more difficult for analysts and investors to assign meaning to the information they gather from a firm, which in turn increases uncertainty and leads to lower stock market prices (Zuckerman 1999). At the same time, the stability of identities is constantly being undermined (Callon et al. 2002) because some actors are interested in changing existing judgements through the introduction of new products or reevaluating existing ones. Existing orders of valuation do not only provide order in the market but also have specific distributive outcomes which are contested. The emerging "market struggle" (Weber) aims at the change or maintenance of value orders and is one essential way in which uncertainty is constantly reintroduced in market fields, and thereby a crucial background to the dynamism of capitalist markets.

(2) On the other hand, the value problem refers to the assignment of value to goods of a certain class, for example automobiles, works of modern art or wine. The value may result from the commodity's functional contribution to solving a specific problem, such as getting from point A to point B, or satisfying one's hunger. Contrary to the assumptions of economic theory, however, there is no evidence that efficient solutions consistently win out, nor can we explain purchase decisions in functionally saturated consumer markets biologically or in terms of objective functional requirements. Thus the question of why actors value certain products and not others is open to sociological analysis. The primary sociological postulate is that the valuation of certain categories of goods is socially and culturally patterned. This can be a normative orientation, a cognitive point of reference or a possibility for social positioning that is "realized" by acquiring a particular good.

The influence of normative assessments can be seen, for instance, in the effects of religious dietary restrictions on the evaluation of certain foods (for example, pork among Muslims and Jews). But it can also be seen in financial markets. Viviana Zelizer's (Zelizer 1979) work on the emergence of the life insurance industry in nineteenth-century America demonstrates the initial blockage of market demand for life insurance by religious (and superstitious) convictions. An illustration of the relevance of normative and cognitive assessments for the valuation of products is also provided by the economically small but theoretically interesting market for whale watching. It did not come into existence until there were profound changes in the symbolic meaning of whales in western culture (Lawrence and Phillips 2004). While for centuries whales were regarded as dangerous and thus menacing giantse.g., in the epochal description by Herman Melville - today they symbolize the value of freedom and of intact nature, and are deemed particularly worthy of protection. Only on the basis of this shift of meaning did the value of life insurance and "whale watching" as products and thus the emergence of a market become possible. Assessments of specific characteristics of goods can form as "rationalized myths" (Meyer and Rowen 1977) within institutional fields. In more general terms, the normative and cognitive framing of markets, anchored in social belief systems, is a constitutive element of their emergence because it shapes the assessment of the desirability and suitability of the products offered and thus reduces uncertainty in 
markets. In this sense, "markets are explicitly moral projects, saturated with normativity" (Fourcade and Healy 2007: 22).

(3) The uncertainty of value attribution is additionally reduced when products facilitate status assignments. In this case the value of goods arises from the social recognition stemming from their possession, which provides "status" to the owner. Luxury products like yachts or antiques provide status because they are associated with high costs that can be covered only by a small group of affluent people or signal cultural capital and thereby enable their owner to demonstrate their social distinction. The capability of goods to signal social status, however, is also an instrument for differentiating the value of heterogeneous products within a market. This can be shown based on the distinction between standard markets and status markets (Aspers 2005). While the value order of products in standard markets is based on the qualities of the product itself, the value order in status markets is based on the social status of the producers and the consumers of the product. A good example for this is the fashion market. The value of the very same handbag changes radically depending on whether it is sold by "Gucci" or by "H\&M" and whether it is seen being carried by a celebrity. Hence the existence of a recognized status order among producers leads to value differentiations because the status of the producer is "contagious"; it is symbolically transferred to the consumer.

The more the value of products becomes detached from the fulfillment of purely functional needs, the more they depend upon symbolic assignments of value that must be constructed by market actors. When consumers are "attached" (Callon et al. 2002) to goods, expectations are stabilized and uncertainty with regard to the value of a product reduced. To understand such attachments, market sociology needs a theory of preference formation, which could be based in socialization theory, learning theory, network analysis, or social movement theory. Talcott Parsons's (Parsons 1949) theory of action establishes the role of the internalization of norms as an important aspect of preference formation. This remains, however, much too general and also too static for understanding the dynamic changes of preferences in markets. Pierre Bourdieu's (Bourdieu 2005) notion of habitus provides an explanation for the valuation of goods based on the cultural capital of consumers (drawing on socialization theory, Bourdieu speaks of habitus as "socialized subjectivity"; Bourdieu 2005: 84). This is of great sociological interest because it connects consumption to social stratification and sees stratification based on differences not only in economic capital but in the accumulation of cultural capital as well. Preferences can be also linked to network ties as can be seen for consumer goods (DiMaggio and Louch 1998; Garvía 2007) and for investment goods (Zuckerman 1999). Social movement theories enable us to explain the cycles in demand, starting with a run on certain products and ending with their sudden demise (Deutschmann 1999: 130; Fligstein 2001b).

A theory explaining preferences for specific goods needs to take the role of producers and consumers into account. Producers attempt to create consumer attachment to their goods through their marketing investments. These activities account for an increasingly large proportion of production costs (Aspers 2005; Callon et al. 2002) and are part of the market struggle between producers. Value attachments, however, are also created in the lifeworlds of consumers, and producers must react to new and often unpredictable trends that emerge. This 
implies that market sociology must put much more emphasis on the demand side of markets.

It is through processes of standardization, cognitive anchoring, normative legitimation, and social positioning that the subjective value attributions arise with which market actors assign value to goods. It is not a question here of all actors assigning the same value to a good, but rather of individual actors being sufficiently convinced by their own valuations to want to acquire the corresponding commodities as buyers in the marketplace. For this they not only rely on institutionalized standards (Fligstein 2001a), network positions of producers (Podolny 2005) or social norms (Zelizer 1979), but they must also take into account a social dimension of their purchases that consists in their communication of social belonging through buying products loaded with intersubjectively recognized meaning. The assignments of value are subject to a dynamic process of change, which is energized by technological or cultural innovations, advanced or impeded by the marketing activities of producers aiming at increased profits, and supported by consumer behavior aimed at the satisfaction of needs, hopes and social distinction (Campbell 1987). In this sense uncertainty is never eliminated from the market but remains a crucial resource that threatens existing sources of profit and providing new profit opportunities for entrepreneurs. The indeterminacy of the situation makes it "problematic" in the sense that it cannot be fully controlled through rational calculation. At the same time it elicits innovative inquiry and will eventually lead to new perspectives on what is valuable (Stark 2009: 15).

The problem of competition

While the issue of valuation refers to the constitution of actor goals and is in this sense prior to market exchange proper, the two remaining coordination problems address the general issue of how market actors can turn their preferences into preferred market outcomes. Now the exchange itself takes center stage. The discussion focuses again on the role of social macrostructures, and on questions of how stable and profit-enabling macrostructures are established in markets and how they change.

The coordination problem to be discussed first is competition. ${ }^{10}$ One of the insights of neoclassical theory is the paradox that while perfect markets are efficient, in market equilibrium the marginal costs equal the marginal returns and thus no profit beyond "the opportunity cost of the equity capital provided by the owner[s] of the firm" (Douma and Schreuder 2002: 30) can be made. Profit becomes possible only when markets find themselves in disequilibrium (Chamberlin 1933; Knight 1985; Robinson 1933). This paradox has profound consequences for the understanding of markets: While competition is a constitutive precondition for markets, it also threatens the profit expectations of producers. Suppliers therefore have an interest in establishing market structures that shield them favorably from competitors, allowing them to reduce uncertainty with regard to their profit or wage

\footnotetext{
${ }^{10} \mathrm{I}$ limit the discussion to competition between producers, leaving out competition on the demand side.
} 
expectations. At the same time, however, this affects the interests of competitors and demanders. Through the deviation from the ideal of perfect markets, market barriers are erected leading to prices that are higher than economically necessary. This conflict of interest constitutes a market struggle (Weber 1978: 72) on the structure of competition, which takes place between market competitors, the state and interest groups on the demand side over the containment, expansion, shaping and regulation of competition (Lie 1997: 345). The behavior of market actors may be understood in the terminology of "getting action" and "blocking action" (White 1992), which describes the intention to gain an advantage over competitors in network terms. The structuration of competition does not only resolve a coordination problem but leads to contested distributional results and is therefore a precarious compromise reflecting the inequalities of the power of actors in the market field. Hence the specific organization of competition is a contingent political and historical phenomenon. For a macrosociology of markets it is the investigation of the evolution of structures of competition and the explanation of its direction which provides access to the understanding of capitalist development (Djelic 2006).

Firms and labor alleviate some of the uncertainty created by competition themselves by product differentiation, first-mover advantages, reciprocal agreements, corruption, collusion, cartels, or by achieving a monopoly position to stabilize their profit opportunities. This also shows the interconnectedness between valuation processes and competition. The creation of consumer "attachment" to specific products leads to their "singularization," creating de facto local monopolies through differentiation, and "is the mainspring of competition" (Callon, Méadel, and Rabeharisoa 2002: 202). Harrison White's (White 1981) market model also portrays the structure of markets in terms of product differentiations that allow producers to position themselves in niches. Regulations of competition devised by the suppliers in the market themselves can rely on institutional forms like standard setting or voluntary agreements that operate as soft law; they can be based on networks such as cartels; and they can be based on cognitive frames such as economic theories (Callon 1998; Miller 2002) or taken-for-granted routine knowledge on how to compete in a given market field (Fligstein 2001a).

However, institutional regulations devised by the state play the most important role in the organization of competition. The state is involved through its legislation, for instance in antitrust law, labor law, or intellectual property law as well as through the introduction of subsidies, duties, and consumer protection measures. The demand side of the market interface is primarily involved in these state-devised regulations through its interest in lower prices, through competition among suppliers and its interest in consumer protection measures (Trumbull 2006). While the role of the state is, on the one hand, to ensure competition despite the interest of powerful firms to reduce it, the state is also engaged in reducing competition among suppliers within its jurisdiction by imposing import tariffs, for example, and-in the case of labor markets - by restricting immigration and allowing for collective bargaining. This means that the state is increasing uncertainty, especially through antitrust law, while reducing it through regulations limiting competition in markets, which shows how contradictory tendencies are simultaneously built into the system. The structuring of competition creates predictability for market actors but only contributes to capitalist growth if uncertainty is not removed altogether through 
the strangulation of competition (Collins 1990: 112). The economic position of suppliers must remain continually threatened by competition for market dynamics to unfold. However, the limitation of competition enabling "reproducible role structures" (White 1981) to develop in markets, is also essential for constituting confidence in investment decisions and shaping the order of markets.

Labor markets are especially important markets with regard to the regulation of competition because they provide the only source of income for a vast majority of the population. They are also important because they demonstrate very obviously how the institutional regulation of competition not only reduces uncertainty by creating stable expectations but establishes economic inequalities and allocates market risks between market actors, i.e., employers, employees, and the state, as well. As stated above, the order of markets depends not just on "stable worlds" (Fligstein 2001a), but also on socially acceptable outcomes. Only if the resulting inequalities are accepted will the organization of economic activities through markets gain the social legitimacy that is itself a precondition for the functioning of markets. While the social and political power exercised in markets leads to significant levels of social inequality (Offe 2006), extreme inequality may result in social protest and thereby even threaten the market system itself. ${ }^{11}$ Hence the operation of markets can only be understood within the larger context of society. Actors demand the regulation of labor markets and may resist marketization, pushing their interests in political struggles. The embeddedness of markets draws strongly on the struggles between economic and social logics in society; markets are as much political arenas as they are economic realms. This aspect of the embeddedness of markets has found scant attention in the new economic sociology so far.

\section{The problem of cooperation}

The problem of cooperation arises from the social risks that market actors incur because of their incomplete knowledge of the intentions of their exchange partners and the quality of the product they wish to purchase. Market relations are risky when one exchange partner makes an advance payment without being sure whether the other party will actually fulfill the contractual obligations, or when contracts are incomplete. The more difficult it is to recognize or specify the quality of a product (Akerlof 1970) and the less able the buyer is to infer the seller's actual intentions from his manifest signals (Bacharach and Gambetta 2001), the greater these risks are. Only when buyers are confident of not being exploited by their contract partners will they engage in market exchange. Creating this confidence is thus a fundamental precondition of stable market relations (Barbalet 1998: 82ff; DiMaggio 2002). Conversely, markets implode as soon as this confidence disappears. A striking example of this, among many, is the panic that breaks out among depositors at banks (allegedly) threatened with insolvency.

Solutions to the problem of cooperation have been discussed widely in the social sciences over the last thirty years, mostly in the context of the notion of trust (Axelrod 1984; Bacharach and Gambetta 2001; Coleman 1990; Cook 2001;

\footnotetext{
${ }^{11}$ This refers to Durkheim's notion of anomic suicide, which is connected in his work with his discussion of unfair prices, especially the price of labor (see Durkheim 1984: 162f; Beckert 2001).
} 
Gambetta 1988; Luhmann 1979). Institutional economics and game theory as well as the new economic sociology have investigated a variety of social mechanisms that contribute to raising ego's estimation of the probability of cooperative action on the part of alter ego, and thus prevent market failure caused by expecting the exchange partner to defect. The different approaches can be categorized largely along disciplinary lines.

Economic advances explain cooperation on an individualistic basis. This can be seen, for instance, in game theoretical approaches, which understand cooperation in prisoner's-dilemma games as a result of the expectation of repeated interactions (iterative games) that change the incentive structures of the players, making cooperation (or conditional cooperation) the rational strategy (Axelrod 1984). A second line of argumentation takes institutions into account that induce cooperative strategies through the effective sanctioning of defectors. These economic approaches are limited: Game theory is unrealistic with regard to the knowledge actors require in a given situation in order to act rationally. To the extent that institutions protecting cooperative relationships are seen as the result of efficient institutional design, the path dependency of institutional development is not taken into account.

Power-oriented approaches proceed from the enforcement of compliance based on the threat of force. Threats to secure cooperation figure especially prominently in illegal markets in which the exchange partners cannot rely upon state-guaranteed legal protection and must ensure cooperation privately, while under pressure of possible state prosecution (Besozzi 2001). While power undoubtedly can play an important role in securing cooperation, its scope does not suffice to explain the integration of market exchange when market relations are voluntary.

Other sociological approaches to the problem of cooperation show how networks and institutions pattern the cooperation between actors. Network approaches view the willingness of actors to accept the social risks of market exchange as a function of the structure of social networks. Mark Granovetter (Granovetter 1985: 490ff, 2005) points to the significance of network structures for the development of trust between market parties. A person who has already had positive experiences with an exchange partner in previous transactions or at least knows a trustworthy person who has had interactions with him or her is more likely to accept the contract risk than an individual for whom the exchange partner is a complete stranger. Networks through which information travels more easily are better equipped to induce cooperative behavior, because their structures facilitate the sanctioning of defectors. Although the extent to which "social capital" can actually be built instrumentally is contested (e.g. Burt 1992), network approaches to cooperation generally analyze social structure as the result of long historical processes (Putnam 1993; Gambetta 1988). Institutionalist approaches in economic sociology regard the exchange partners' normative or cognitive commitment to institutionalized rules as key to explaining cooperative behavior. Even the highly stratetegic trading relations of currency dealers on financial markets are regulated by rules of conduct that govern the exchange and are enforced by an informal honor code and sanctioned when violated (Knorr-Cetina and Bruegger 2002: 936ff).

There is no guarantee that networks, social norms or tradition effectively enhance cooperation, and it is also evident that some cooperation in markets is disadvantageous to economic welfare. Highly fragmented network structures are detrimental to 
cooperation (Granovetter 1973: 1373f), as are non-universalist ethical orientations, which prescribe cooperative behavior in exchange with members of the same ethnic group but not in exchange with outsiders (Portes and Sensenbrenner 1993). Moreover, collusion between "competitors" can be a source of inefficiency and economic exclusion. However, whether restraints on individual rationality are "beneficial" (Streeck 1997) is also a question of perspective: Beneficial for whom? Market actors benefit and suffer differently from existing constraints and might gain advantages from free-riding; they will therefore engage in struggles to either change, defend, or exploit existing cooperative structures and rules as part of the "market struggle." While lasting market relations would be impossible without stabilized expectations regarding the cooperation of exchange partners, the possibility of defection remains, and is merely "suspended" (Möllering 2006) by trust between the exchange partners. Why people "suspend" the suspicion of getting exploited "cannot be conceived or implemented from within a theory of behavior that admits only of rational action" (Granovetter 2002: 40).

\section{The dynamics of markets}

Studying markets from the perspective of the problem of social order initially leads to a foregrounding of static elements. It is a matter of creating stable expectations for actors by reducing the contingency entailed in the freedom of alter ego, which gives the decision makers the confidence to be able to make investment and consumer decisions that will, by and large, not lead to disappointing outcomes. Such "stable worlds" (Fligstein 2001a) are a precondition for the expansion of markets. Historically, the emergence of modern, rational capitalism may be viewed as a process of developing institutional regulations, ethical action orientations and socio-structural linkages, which have made it possible to contain the coordination problems discussed here (Berghoff 2004; Block and Evans 2005; Fligstein 2001a; Hellmann 2003; Weber 1992; Zucker 1986).

In the discussion of the three coordination problems, I have indicated that the processes of creating stability of expectations represent only one side of market coordination. Value attributions change, profitable competitive positions are threatened by new products or altered regulations, and the danger of defection persists despite institutional safeguards, social norms, and cooperation enhancing network structures. Though "stable expectations" are preconditions for market exchange, they do not remove the essential element of uncertainty from economic decision-making. Instead, the coexistence of "stable worlds" and uncertainty is an unavoidable state of affairs for capitalist economies and an indispensable precondition for their dynamics.

Empirically speaking, capitalist economies are characterized by the systematic expansion and continual renewal of uncertainty (cf. Deutschmann 2007). This uncertainty can result from exogenously caused crises but stems mostly from the innovative dynamism of capitalism itself, the connection of previously isolated markets, and the substantive and geographical expansion of markets through changes in the competitive structure (Fligstein 2001a: 32). In competitive economies, innovations endanger the economic value of the products they seek to 
replace. The same holds true for new regulations or the deregulation of markets. The extension of the competitive mechanism as a result of political and social struggles introduces uncertainty into fields of action heretofore subject to institutional constraints (Weber 1978: 635ff; Polanyi 1957). The emergence of labor markets is the most important example of this. An investigation of the historical processes influencing the development of multiple forms of market regulation, and of the ways they subsequently change, opens the analysis of markets to the macrodimensions of the evolution and varieties of capitalism (Djelic 2006).

Theoretically, the relationship between uncertainty and profits demonstrates the constitutive significance of "zones of unpredictability" for the capitalist economy. Frank Knight (Knight 1985) has pointed out that under conditions where a calculus of risks is possible, what neoclassical theory showed for perfect markets applies: there are no profits. Only situations containing uncertainty make room for entrepreneurial action in the Schumpeterian sense. Although market transactions are always institutionally and sociostructurally embedded, actors inevitably face imponderables that constitute the uncertainties and opportunities upon which capitalist dynamism is based.

The nexus of the necessary reduction of uncertainty through the embeddedness of market exchange and the simultaneous preservation of a "realm of unpredictability" can be used to build a model of the dynamic character of capitalism centred on the notion of "dynamic disequilibrium." By this term I allude to the continuous processual changes built into capitalist accumulation that are not moving toward a static equilibrium but reflect permanent contestation in the economic field, where actors with partly overlapping, partly opposing interests engage in "control efforts" (White 1992: 9ff) to shape and use social macrostructures to enhance their goals. These control projects and their dynamic characters have social preconditions that are partly systemic, partly institutional and partly rooted in the capabilities of human actors.

(1) The systemic preconditions for the unprecedented dynamism of modern capitalism can be described on two levels. On the level of market competition, "free-market pressures force firms into a continuing process of innovation" (Baumol 2002: viii). On the level of capital accumulation, capital owners are forced to constantly seek new opportunities for investment, from which they expect to derive profits (Deutschmann 1999: 130ff).

(2) Institutionally, it is precisely the expansion of markets and the concurrent anchoring of competition as the basis of the organization of economic production and distribution that constitutes an environment that is comparatively open to change through deviant behavior. Competition constantly forces suppliers to seek out new opportunities in order to make profitable investments. The (ideal and typically viewed) curbing of traditional limitations and restrictions on the exercise of hierarchical power in markets favors innovation (Beckert 1999: 792f). Also one can point to the contradictions and mutually undermining dynamics of the institutions contextualizing market behavior which can lead to endogenous change dynamics. Established social arrangements produce "a complex array of contradictions, continually generating tensions and conflicts within and across social systems, which may, under some circumstances, shape consciousness and 
action to change the present order" (Seo and Creed 2002: 225). Emerging institutional contradictions may open up new opportunities, leading to responses which make different regulations possible or create new networks which shift the composition of power in the market field. The embeddedness of markets consists of so many, sometimes contradictory, institutional facets that solutions in one area cause new problems elsewhere, leading to a permanent process of opening up opportunities for endogenously triggered change (Schneiberg 2005; Leblebici et al. 1991).

(3) On the actor level, the dynamic processes of continuous change are rooted in the human ability to envision future states of the world and, based on these visions, to abandon routinized behavior (Beckert 2003: 775). In Joseph Schumpeter's (Schumpeter 1934, 1991), concept of "creative destruction," this "creativity of action" (Joas 1996) became the starting point for a theory of the dynamism of capitalism based on the "creative reconstruction of social patterns on the basis of a reasoned analysis" (Seo and Creed 2002: 225). ${ }^{12}$

These general considerations regarding change can be related to the three coordination problems identified above. Entrepreneurs are systematically trying to change consumers' value attachments by attempting to convince them of the (superior) value of their products. Their success contributes in turn to the devaluation of the products substituted, hence creating uncertainty in the market. This process is fueled not only by market suppliers, but also by consumers looking for new ways to express status differentiation and lifestyles and to create "self-illusionary experiences" (Campbell 1987: 89) constructed from the meanings associated with products. At the same time entrepreneurs are seeking to remodel the structures of competition in ways that provide more favorable market positions for them. If they succeed, this results in regulatory changes that re-configure markets and thereby create dynamism. Finally, entrepreneurs are trying to induce others to cooperate with them by investing in activities that signal the trustworthiness of their products, promising new ways to create value, and forming coalitions or social movements in markets which align others' behavior with their own intentions (Davis, et al. 2004; DiMaggio 2002; Stark 2009; White 1992). The opportunities for change emerge from the dynamic interactions between the social macrostructures including technological changes; the developing contradictions are being exploited by entrepreneurs who change the way the market is embedded.

In capitalist economies, the complex embeddedness of markets comes up against actors' motivations to find new ways to secure profits or utility and contradictory institutional configurations that lead to a continual challenging of existing institutions, networks, products, and technologies by innovation. This perpetually renews the uncertainty for actors - paradoxically precisely in the attempt to master it. Deviant action produces both the profit opportunities that provide the incentive to produce for the market and the destabilization that forces other actors to adapt, and

\footnotetext{
${ }^{12}$ Following Christoph Deutschmann (Deutschmann 1999, 2007), the significance of this quality of action for the capitalist economy can be extended still further: creativity is not merely a typical feature of entrepreneurial action, but rather a characteristic of free labor power as such. "Added value," the argument goes, arises from exhausting the creative potential of human resources in the production process, the results of which are never predictable.
} 
that must be mitigated by the socio-structural, institutional, and cultural embeddedness of markets. In this way the market struggle between competitors leads to states of disequilibrium, which are constantly changing.

\section{Conclusion}

If one views market action from the perspective of the three coordination problems, the focus is on the interaction between actors and their institutional, cultural, and social embeddedness. These social macrostructures and their dynamic changes play a more fundamental role in the study of ordering processes in markets than the price mechanism foregrounded in neoclassical theory (Hayek 1973: 115ff). Although changes in prices emerge from changes in supply and demand, these changes themselves are the result of the social, institutional and cognitive structures of markets. Hence prices are not seen as the aggregate result of individual preferences but rather as the outcome of social macrostructures patterning economic action.

The approach to the sociology of markets suggested in this article seeks to understand how coordination problems are solved in order to account for why, and under what conditions, markets become successful devices for the organization of economic activities. The concern is, on the one hand, with the constitution of actor preferences, which are explained based on normative, cultural, and social structural influences stemming from the social context in which market actors live. On the other hand, the sociology of markets aims to understand how market actors realize their preferences in the exchange process. Here they are confronted with two further coordination problems: competition and cooperation. Again, the assumption underlying the sociology of markets is that these problems are resolved based on the regulative influence of social macrostructures - institutions, social networks, and cognitive structures.

The challenge for the sociology of markets is to show how these structural forces actually influence market outcomes, and to explain in detail how the macrostructures emerge, stabilize, and change in processes of social interaction. Contrary to economic institutionalism, it is not assumed that social macrostructures can be explained by the efficiency concerns of market actors. It is not just the complexities of decision-making, but also collective action dilemmas and the historicity of institutions and networks that refute this reductionist view. Instead, social macrostructures are seen as historical manifestations of material and ideal interests of actors commanding the social and political power to shape market fields. The development of the macrostructures prevailing in markets needs to be understood as a political, social, and cultural process which can be explained only by following the historical development of the evolution of specific markets.

Just as the influence of institutions, networks, and cognition on the interaction processes of market exchange is an important field for the sociology of markets, so is the emergence and change of these structures. How do actors' preferences interact with the social macrostructures that form the conditions for action in the exchange process? We have little systematic knowledge of how social macrostructures translate into preferences and the behavior of actors. It is not enough to look at social macrostructures as constraints on action, and explain outcomes as rational or culturally infused responses 
to these constraints. Neither rationalist interpretations nor cultural and morphological determinism do justice to the contingency of interpretations of social macrostructures by agents (Jagd 2007: 78). Although the meaning that a social situation attains for actors, as well as their reactions, are influenced by cultural templates, institutions, or network positions, they are not determined by them. These issues can be explored by studying diverse markets empirically and historically with an eye to the coordination problems discussed here. The broadest objective of this undertaking is to develop a "sociological theory of economic action" (Weber 1978 Vol. 1: 68).

Acknowledgments I want to thank Patrik Aspers, Marie-Laure Djelic, Rudolf Richter, Marc Schneiberg, Richard Swedberg, and two Theory and Society reviewers for their insightful comments. Parts of the text are based on a translation by Pamela Selwyn.

Open Access This article is distributed under the terms of the Creative Commons Attribution Noncommercial License which permits any noncommercial use, distribution, and reproduction in any medium, provided the original author(s) and source are credited.

\section{References}

Akerlof, G. A. (1970). The market for "lemons": Quality uncertainty and the market mechanisms. Quarterly Journal of Economics, 84, 488-500.

Aspers, P. (2005). Status and standard markets in the global fashion industry. Cologne: Max-Planck-Institut für Gesellschaftsforschung. Vol. 05/10.

Aspers, P., \& Beckert, J. (2008). Märkte. In A. Maurer (Ed.), Handbuch der Wirtschaftssoziologie (pp. 225-246). Wiesbaden: VS-Verlag.

Axelrod, R. (1984). The evolution of cooperation. New York: Basic Books.

Bacharach, M., \& Gambetta, D. G. (2001). Trust in Society. In K. S. Cook (Ed.), Trust in society (pp. 148-184). New York: Russell Sage.

Barbalet, J. (1998). Emotion, social theory, and social structure: A macrosociological approach. Cambridge: Cambridge University Press.

Baumol, W. J. (2002). The free-market innovation machine: Analyzing the growth miracle of capitalism. Princeton University Press.

Becker, H. S. (1982). Art worlds, berkeley and los angeles. Berkeley: University of California Press.

Beckert, J. (1996). What is sociological about economic sociology? Uncertainty and the embeddedness of economic action. Theory and Society, 25(6), 803-840.

Beckert, J. (1999). Agency, entrepreneurs and institutional change: The role of strategic choice and institutionalized practices in organizations. Organization Studies, 20, 777-799.

Beckert, J. (2001). Contract and social justice. Emile Durkheim's theory of integration of modern societies. In W.S.F. Pickering (Ed.), Emile Durkheim: Critical assessments leading sociologists (pp. 290-311). London: Routledge.

Beckert, J. (2002). Beyond the market. The social foundations of economic efficiency. Princeton: Princeton University Press.

Beckert, J. (2003). Economic sociology and embeddedness. How shall we conceptualize economic action? Journal of Economic Issues, 37, 769-787.

Beckert, J. (2007). The great transformation of embeddedness. Karl Polanyi and the New Economic Sociology. Köln: Max-Planck-Institut für Gesellschaftsforschung. Vol. 07/1.

Beckert, J., \& Rössel, J. (2004). Kunst und Preise. Reputation als Mechanismus der Reduktion von Ungewissheit am Kunstmarkt. Kölner Zeitschrift für Soziologie und Sozialpsychologie, 56, 32-50.

Berghoff, H. (2004). Die Zähmung des entfesselten Prometheus. In H. Berghoff, \& J. Vogel (Eds.), Wirtschaftsgeschichte als Kulturgeschichte. Dimensionen eines Perspektivenwechsels (pp. 143-168). Frankfurt a.M.: Campus.

Besozzi, C. (2001). Illegal, legal - egal? Zur Entstehung, Struktur und Auswirkungen illegaler Märkte. Bern: Paul Haupt. 
Block, F., \& Evans, P. (2005). The state and the economy. In N. J. Smelser, \& R. Swedberg (Eds.), The handbook of economic sociology (pp. 505-526). Princeton: Princeton Universtiy Press.

Bourdieu, P. (1999). Die Regeln der Kunst. Genese und Struktur des literarischen Feldes. Frankfurt: Suhrkamp.

Bourdieu, P. (2005). Principles of an economic anthropology. In N. J. Smelser, \& R. Swedberg (Eds.), The handbook of economic sociology (pp. 75-89). Princeton: Princeton University Press.

Burt, R. (1992). Structural holes: The social structure of competition. Cambridge: Harvard University Press.

Callon, M. (Ed.) (1998). The laws of the markets. Oxford: Blackwell.

Callon, M., Méadel, C., \& Rabeharisoa, V. (2002). The economy of qualities. Eonomy and Society, 31, 194-217.

Campbell, C. (1987). The romantic ethic and the spirit of modern consumerism. Oxford: Basil Blackwell.

Carruthers, B. (1994). When is the state autonomous? Culture, organization theory and the political sociology of the state. Sociological Theory, 12, 19-44.

Carruthers, B. (2005). Historical sociology and the economy: Actors, networks and context. In J. Adams, E. S. Clemens, \& A. S. Orloff (Eds.), Remaking modernity (pp. 333-354). Durham: Duke University Press.

Carruthers, B., \& Halliday, T. (1998). Rescuing business: The making of corporate bankruptcy law in England and the United States. Oxford: Clarendon.

Chamberlin, E. (1933). The theory of monopolistic competition. Cambridge: Cambridge University Press.

Coase, R. H. (1988). The firm, the market and the law. In R. H. Coase (Ed.), The firm, the market and the law (pp. 1-31). Chicago: University of Chicago Press.

Coleman, J. S. (1990). Foundations of social theory. Cambridge: Harvard University Press.

Collins, R. (1990). Market dynamics as the engine of historical change. Sociologcal Theory, 8, 111-135.

Cook, K. S. (Ed.) (2001). Trust in society. New York: Russell Sage.

Davis, Gerald, et al. (Eds.) (2004). Social movements and organization theory. Oxford: Oxford University Press.

Deutschmann, C. (1999). Die Verheißung des absoluten Reichtums. Zur religiösen Natur des Kapitalismus. Frankfurt a.M.: Campus.

Deutschmann, C. (2007). Der Euro als Symbol Europas. Zum Problem der Wirtschaftslastigkeit der europäischen Integration. Die Grenzen Europas. Trient (30.3.2007).

Diaz-Bone, R. (2005). Strukturen der Weinwelt und der Weinerfahrung. Sociologia Internationalis, 43, 25-57.

DiMaggio, P. (1994). Culture and economy. In N. Smelser, \& R. Swedberg (Eds.), The handbook of economic sociology (pp. 27-57). New York and Princeton: Russell Sage Foundation and Princeton University Press.

DiMaggio, P. (2002). Endogenizing "animal spirits": Toward a sociology of collective response to uncertainty and risk. In M. F. Guillén, et al. (Ed.), The new economic sociology. Developments in an emerging field (pp. 79-100). New York: Russell Sage.

DiMaggio, P. J., \& Louch, H. (1998). Socially embedded consumer transaction: For what kinds of purchases do people most often use networks? American Sociological Review, 63, 619-637).

Djelic, M.-L. (2004). Social networks and country-to-country transfer: Dense and weak ties in the diffusion of knowledge. Socio-Economic Review, 2, 341-370.

Djelic, M.-L. (2006). Marketization: From intellectual agenda to global policy-making. In M.-L. Djelic, \& K. Sahlin-Andersson (Eds.), Transnational governance. Institutional dynamics of regulation (pp. 5373). Cambridge: Cambridge University Press.

Djelic, M.-L., \& Quack, S. (2007). Overcoming path dependency: Path generation in open systems. Theory and Society, 36(2), 161-186.

Dobbin, F. (1994). Forging industrial policy. The United States, Britain and France in the Railway Age. Cambridge: Cambridge University Press.

Dobbin, F. (2004a). Introduction: The sociology of the economy. In F. Dobbin (Ed.), The sociology of the economy (pp. 1-25). New York: Russell Sage Foundation.

Dobbin, F. (2004b). The sociological view of the economy. In F. Dobbin (Ed.), The new economic sociology. A reader (pp. 1-46). Princeton: Princeton University Press.

Douma, S., \& Schreuder, H. (2002). Economic approaches to organizations, 3rd. edition. Essex: Pearson Education LImited. [1991]

Durkheim, E. (1947). On the division of labor in society. New York: The Free Press [1893].

Durkheim, E. (1984). The division of labour in society, contemporary social theory. London: Macmillan [1893]. 
Eymard-Duvernay, F., \& Marchal, E. (1997). Façons de Recruter. Le Jugement des Compétences sur le Marché du Travail. Paris: Editions Métailié.

Fiss, P. C., \& Kennedy, M. T. (2007). Framing markets. 23rd EGOS Colloquium 2007, Sub-theme 36: Innovation and Institutions. Vienna, Austria.

Fligstein, N. (1996). Markets as politics: A political-cultural approach to market institutions. American Sociological Review, 61, 656-673.

Fligstein, N. (2001a). The architecture of markets. Princeton: Princeton University Press.

Fligstein, N. (2001b). Social skill and the theory of fields. Sociologcal Theory, 19, 105-125.

Fligstein, N. D., \& Dauter, L. (2007). The sociology of markets. Annual Review of Sociology, 33, 105-128.

Fourcade, M. (2007). Theories of markets and theories of society. American Behavioral Scientist, 50, 1015 1034.

Fourcade, M., \& Healy, K. (2007). Moral views of market society. Annual Review of Sociology, 33, 285311.

Gambetta, D. (1988). Can We Trust Trust? In D. Gambetta (Ed.), Trust. making and breaking cooperative relations. New York: Basil Blackwell.

Garvía, R. (2007). Sindication, institutionalization and lottery play. American Journal of Sociology, 113, 603-653.

Gould, M. (1991). Parsons' economic sociology: A failure of will. Sociological Inquiry, 61, 89-101.

Granovetter, M. (1973). The strength of weak ties. American Journal of Sociology, 78, 1360-1380.

Granovetter, M. (1985). Economic action and social structure: The problem of embeddedness. American Journal of Sociology, 91, 481-510.

Granovetter, M. (2002). A theoretical agenda for economic sociology. In M. Guillen, et al. (Ed.), The new economic sociology: Developments in an emerging field (pp. 35-59). New York: Russell Sage Foundation.

Granovetter, M. (2005). The impact of social structure on economic outcomes. Journal of Economic Perspectives, 19, 33-50.

Greif, A. (2006). Institutions and the path to the modern economy. Cambridge: Cambridge University Press.

Hall, P., \& Soskice, D. (2001). Introduction. In P. Hall, \& D. Soskice (Eds.), Varieties of capitalism. The institutional foundations of comparative advantage (pp. 1-45). Oxford: Oxford University Press.

Hayek, F. A. von (1973). Law, legislation and liberty. A new statement of the liberal principles of justice and political economy. Chicago: The University of Chicago Press.

Hellmann, K. U. (2003). Soziologie der Marke. Frankfurt a.M.: Suhrkamp.

Hirschman, A. O. (1986). Rival views of market society. New York: Viking.

Hirschman, A. O. (1987). Leidenschaften und Interessen. Politische Begründungen des Kapitalismus vor seinem Sieg. Frankfurt a.M.: Suhrkamp.

Jagd, S. (2007). Economics of convention and new economic sociology. Mutual inspiration and dialogue. Current Sociology, 55, 76-91.

Joas, H. (1996). The creativity of action. London: Polity.

Klein, D. B. (1997). Convention, social order, and the two coordinations. Constitutional Political Economy, 8, 319-335.

Knight, F. H. (1985). Risk, uncertainty, and profit. Chicago: University of Chicago Press [1921].

Knorr-Cetina, K., \& Bruegger, U. (2002). Global microstructures: The virtual societies of financial markets. American Journal of Sociology, 107, 905-950.

Koçak, Ö. (2003). Social orders of exchange: Effects and origins of social order in exchange markets. $\mathrm{PhD}$ thesis, Stanford: Stanford University.

Krippner, G. (2001). The elusive market: Embeddedness and the paradigm of economic sociology. Theory and Society, 30(6), 775-810.

Latsis, S. (1972). Situational determinism in economics. British Journal of Philosophy of Science, 23, 207-245.

Lawrence, T. B., \& Phillips, N. (2004). From moby dick to free willy: Macro-cultural discourse and institutional entrepreneurship in emerging institutional fields. Organization, 11, 689-711.

Leblebici, H., et al. (1991). Institutional change and the transformation of interorganizational fields: An organizational history of the U.S. broadcasting industry. Adminstrative Science Quarterly, 36, 333363.

Lie, J. (1992). The concept of mode of exchange. American Sociological Review, 57, 508-523.

Lie, J. (1997). Sociology of markets. Annual Review of Sociology, 23, 341-360.

Luhmann, N. (1979). Trust and power. Two works by Niklas Luhmann. Chichester: John Wiley. 
MacKenzie, D., \& Millo, Y. (2003). Constructing a market, performing theory: The historical sociology of a financial derivatives exchange. American Journal of Sociology, 109, 107-145.

MacKenzie, D., Muniesa, F., \& Siu, L. (Eds.) (2007). Do economists make markets? On the performativity of economics. Princeton: Princeton University Press.

Meyer, J. W., \& Rowen, B. (1977). Institutionalized organizations: Formal structure as myth and ceremony. American Journal of Sociology, 83, 340-363.

Miller, D. (2002). Turning Callon the right way up. Economy and Society, 31, 218-233.

Möllering, G. (2006). Trust: Reason, routine, reflexivity. Oxford: Elsevier.

North, D. (1990). Institutions, institutional change, and economic performance. Cambridge: Cambridge University Press.

Offe, C. (2006). Macht oder ökonomisches Gesetz? Erneuter Besuch bei einem alten Thema. Berlin.

Parsons, T. ([1937], 1949) The structure of social action. A study in social theory with special reference to a group of recent European writers. Glencoe: Free.

Podolny, J. (2005). Status signals. A sociological study of market competition. Princeton: Princeton University Press.

Polanyi, K. (1957). The great transformation. Boston: Beacon [1944].

Portes, A., \& Sensenbrenner, J. (1993). Embeddedness and immigration: Notes on the determinants of economic action. American Journal of Sociology, 98, 1320-1350.

Putnam, R. D. (1993). Making democracy work: Civic traditions in modern Italy. Princeton: Princeton University Press.

Richter, R. (2000). Macroeconomics from the viewpoint of modern institutional economics. Saarbrücken: Universität des Saarlandes.

Richter, R., \& Furubotn, E. G. (2003). Neue Institutionenökonomik, Neue ökonomische Grundrisse (3rd ed.). Tübingen: Mohr Siebeck.

Robinson, J. (1933). The economics of imperfect competition. London: MacMillan.

Rössel, J. (2007). Ästhetisierung, Unsicherheit und die Entwicklung von Märkten. In J. Beckert, R. DiazBone, \& H. Ganssmann (Eds.), Märkte als soziale Strukturen. Frankfurt/M.: Campus.

Samuelson, P. (1938). A note on the pure theory of consumers' behaviour. Economica, 5, 61-71.

Schneiberg, M. (2005). Combining new institutionalisms: Explaining institutional change in American property insurance. Sociological Forum, 20, 93-137.

Schotter, A. (1981). The economic theory of social institutions. Cambridge: Cambridge University Press.

Schumpeter, J. (1934). Theory of economic development: An inquiry into profits, capital, credit, interest and the business cycle. Cambridge: Harvard University Press [1911].

Schumpeter, J. (1991). Comments on a plan for the study of entrepreneurship. In R. Swedberg (Ed.), The economics and sociology of capitalism (pp. 406-428). Princeton: Princeton University Press [1946].

Segalla, M., Sauquet, A., \& Turati, C. (2001). Symbolic vs functional recruitment: Cultural influences on employee recruitment policy. European Management Journal, 19, 32-43.

Seo, M. G., \& Creed, W. E. (2002). Institutional contradictions, praxis, and instiutional change: A dialectical perspective. The Acadamy of Management Review, 27, 222-247.

Simon, H. (1955). A behavioral model of rational choice. Quarterly Journal of Economics, 69, 99-118.

Smith, A. (1976). The wealth of nations. Chicago: University of Chicago Press [1776].

Stark, D. (2009). Creative dissonance. Heterarchy and the search for worth. Princeton: Princeton University Press (forthcoming).

Stigler, G. (1961). The economics of information. Journal of Political Economy, 75, 278-292.

Stigler, G., \& Becker, G. S. (1977). De Gustibus Non Est Disputandum. American Economic Review, 67, 76-90.

Storper, M., \& Salais, R. (1997). Worlds of production. Cambridge: Harvard University Press.

Streeck, W. (1997). Beneficial constraints: On the economic limits of rational voluntarism. In R. Hollingsworth, \& R. Boyer (Eds.), Contemporary capitalism. The embeddedness of institutions (pp. 197-219). Cambridge: Cambridge University Press.

Streeck, W., \& Thelen, K. (2005). Introduction. In W. Streeck, \& K. Thelen (Eds.), Beyond continuity (pp. 1-39). Oxford: Oxford University Press.

Swedberg, R. (2003). Economic and sociological approaches to markets. In R. Swedberg (Ed.), Principles of economic sociology. Princeton: Princeton University Press.

Trumbull, G. (2006). Consumer capitalism. politics, product markets, and firm strategy in France and Germany, cornell studies in political economy. Ithaca: Cornell University Press.

Velthuis, O. (2003). Symbolic meanings of prices. Constructing the value of contemporary art in Amsterdam and New York Galleries. Theory and Society, 32, 181-215.

Weber, M. (1978). Economy and society. Berkeley: University of California Press [1922]. 
Weber, M. (1985). Wirtschaft und Gesellschaft. Grundriß der verstehenden Soziologie. 5. Edition. Tübingen: Mohr Siebeck. [1922]

Weber, M. (1992). The Protestant ethic and the spirit of capitalism. London: Routledge [1930].

White, H. (1981). Where do markets come from? American Journal of Sociology, 87, 517-547.

White, H. (1990). Interview: Harrison C. White. In R. Swedberg (Ed.), Economics and sociology (pp. 7895). Princeton: Princeton University Press.

White, H. C. (1992). Identity and control. A structural theory of social action. Princeton: Princeton University Press.

White, H. C. (2001). Markets from networks. Socioeconomic models of production. Princeton: Princeton University Press.

Williamson, O. (1975). Markets and hierarchies. New York: Free.

Williamson, O. (1985). The economic institutions of capitalism. New York: Free.

Williamson, O. (2000). The new institutional economics: Taking stock, looking ahead. Journal of Economic Literature, 38, 595-613.

Zelizer, V. (1979). Morals and markets: The development of life insurance in the United States. New York: Columbia University Press.

Zelizer, V. (1994). The social meaning of money: Pin money, paychecks, poor relief, and other currencies. New York: Basic Books.

Zelizer, V. (2007). Pasts and futures of economic sociology. American Behavioral Scientist, 50, 10561069.

Zucker, L. (1986). The production of trust: Institutional sources of economic structure, 1840-1920. In B. Staw, \& L. L. Cummings (Eds.), Research in organizational behavior (pp. 53-111). Boulder. CO: JAI.

Zuckerman, E. W. (1999). The categorical imperative: Securities analysts and the illegitimacy discount. American Journal of Sociology, 104, 1398-1438.

Zukin, S., \& DiMaggio, P. (1990). Introduction. In S. Zukin, \& P. DiMaggio (Eds.),Structures of capital. The social organization of the economy (pp. 1-36). Cambridge: Cambridge University Press.

Jens Beckert is Professor of Sociology and Director of the Max Planck Institute for the Study of Societies in Cologne. Book publications include Inherited Wealth, Princeton University Press, 2008; Beyond the Market: The Social Foundations of Economic Efficiency, Princeton University Press 2002; and the International Encyclopedia of Economic Sociology (co-edited with Milan Zafirovski), Routledge 2006. His research focuses on the fields of economic sociology, sociology of inheritance, organization studies, and social theory. 